\title{
The Effect of Pandemic Covid-19 into Internship Activity of Mojokerto Vocational High Schools
}

\author{
${ }^{1}$ Andri Setiyawan *, ${ }^{2}$ Arief Kurniawan \\ Email : andrisetiyawan@mail.unnes.ac.id* \\ *: coresponndensing author \\ ${ }^{1}$ Department of Mechanical Engineering Universitas Negeri Semarang \\ ${ }^{2}$ Universitas Ahmad Dahlan, Jl.Pramuka No.42, Pandeyan, Umbulharjo, Yogyakarta, Indonesia
}

Article history

Received May 04, 2021

Revised May 24, 2021

Accepted May 31, 2021

Keywords

Pandemic

Internship

vocational high schools
This study aims to determine what steps were taken by the Vocational High School (VHS) 1 Mojokerto in implementing Dual System Education / Internship which is a mandatory activity for high school students to improve students' insights and qualities and foster good relations between a vocational high school and a job provider company during the COVID-19 pandemic. This research is qualitative research that aims to describe the implementation of Dual System Education / Internship by Vocational high School 1 Mojokerto during the COVID-19 pandemic. The Effect of Pandemic Covid-19 into Internship Activity on apprenticeship: 1) During the pandemic, halt the internship process; internship operations can resume after the pandemic has passed. (2) Relocating student street vendors to businesses that follow government and corporation laws and require the use of personal protective equipment (PPE). (3) Internships will be phased out in favor of online learning.

This is an open access article under the CC-BY-SA license.

\section{Introduction}

Vocational High School (VHS) is one of the national education systems that seeks to equip students with skills or expertise through the Dual System Education (PSG) program or what is often called Prakerin. VHS is an implementation of Technical and Vocational Education Training (TVET) in Indonesia. According to Putu Sudira[1], TVET always keeps schools closer to the business world and the industrial world (DUDI) [2]. Vocational High School (VHS) is a formal education that provides vocational education at the secondary education level as a continuation of SMP / MTs or other forms which are equivalent or advanced from learning outcomes equivalent to SMP / MTs (Law Number 20 of 2003, Article 18 paragraph 3 )[3]. Secondary vocational education, secondary education, which prepares students, especially to work in certain fields, (Law Number 20 of 2003, Elucidation of Article 15) [3].

The internship is an absolute prerequisite for the introduction of technical education. This is the primary reason for the introduction of internships in most technical education institutions 
[4]. Internship is an absolute requirement for the implementation of vocational education. This is the main basis for most vocational education institutions in implementing internship [2]. In the implementation of vocational education, there is an activity that requires students to go directly into the world of work. This activity is commonly called fieldwork practice. Field Work Practice [5] is a form of professional expertise education which is inspired by the dual education system originating from Germany, which combines systematically and synchronously between educational programs in schools and business programs obtained through direct work activities in the business / industrial world for achieve a level of professional expertise. Where professional expertise can only be formed through three main elements, namely science, technique and tips. Science and engineering can be studied and mastered whenever and wherever we are. Meanwhile, tips cannot be taught but can be mastered through the process of doing work directly in the professional field itself. In addition, awareness of the need to introduce students to the world of industry is the biggest impetus for vocational education institutions to organize internship programs [6].

In addition to strengthening the link and match between VHS and Industry, cooperation in the implementation of street vendors, between VHS and the business / industrial world is carried out in the principle of helping each other, complementing each other, and complementing each other for mutual benefit [6]. The implementation of internship still does not have a definite standard of time for its implementation. The implementation of regular internship ranges from 36 months by adjusting the regulations that apply in each school [7].

However, in early 2020 the world was being shaken by the emergence of a virus called COVID-19 (Coronavirus Disease - 2019). This virus is a contagious disease caused by a newly discovered type of coronavirus, which originated in Wuhan City, China. COVID-19 can cause respiratory infections, ranging from the common cold to serious illnesses, such as MERS and SARS. This virus can spread through human physical contact, and crowds also greatly influence the spread of this virus. The government's physical distancing policy to prevent transmission of the covid-19 virus caused changes in learning patterns from face-to-face learning to distance education [8].

\section{Method}

This research uses descriptive qualitative research. Bogdan and Tylor (1989) define descriptive qualitative research as a research procedure that produces descriptive data in the form of written or spoken words from the person or observed behavior [9]. This research took place at Mojokerto VHS. The choice of this place is because this school replaces the implementation of street vendors for students to learn from home due to the Corona virus pandemic. 


\section{Result and Discussion}

The data obtained from interviews with the principal, head of street vendors, and 2 teachers of Mojokerto VHS. The Covid-19 pandemic has an impact on changing the learning model in Indonesia, from conventional learning to virtual learning[10]. Internship is an annual activity carried out by every VHS in Indonesia. internship aims to develop students' talents and strengthen the professionalism of work needed by students to enter the world of work in accordance with their fields. Headmaster said, "Generally, internship is carried out by vocational students with a time span that varies from 3 months to 1 year, but due to the outbreak of the COVID-19 pandemic in the world since December 2019 until now, this virus continues to spread throughout the world and Indonesia is even affected". Therefore, as a preventive measure to prevent the spread of the COVID-19 virus in Indonesia, the government issued regulations that urge all Indonesian citizens to reduce outdoor activities such as gathering and so on, including the policy of Learning from Home and Working from Home, which causes schools to empty. including VHS and industries related to internship activities

Therefore, the head of internship vocational schools said student internship activities will certainly be disrupted and cannot take place as it should, this forces the school to think about how the solutions must be implemented regarding internship during the COVID-19 pandemic, and things that can be done by schools include: Stop the internship process during the pandemic and internship activities will continue after the pandemic has subsided. Moving the location of student street vendors to companies that continue to operate by adhering to government and company regulations and requiring the use of personal protective equipment (PPE). Eliminate internships and replace them with online learning.

At the time of the COVID-19 pandemic, VHS Negeri 1 Mojokerto was doing it by attracting students who were currently attending to follow a circular from the Head of the East Java Provincial Education Office No.420 / 1880 / 101.1 / 2020 on March 21, 2020 regarding not continuing to anticipate the spread of COVID. -19 in the education unit and a circular of the Governor of East Java No.420 / 1950 / 101.1 / 2020 on March 24, 2020 regarding the implementation of education policies in the emergency period of the spread of COVID-19 in East Java, then on March 30, 2020 the Head of VHS Negeri 1 Mojokerto make a internship student withdrawal letter and replace the internship program with additional learning online VHS the Google Classroom application which contains learning material according to their respective majors as well as info and appeals regarding the COVID-19 epidemic such as good and correct handwashing guides and directions and so on. The teacher 1 VHS 1 Mojokerto also uses whatsapp social media to communicate and discuss the material that has been provided through the Google Classroom so that students can be monitored and remain active in following explanations from 
the teacher in whatsapp group and actively discussing even though students are only at home.

The first teacher conveyed that at first there were problems in online learning, but with teacher training from technology-based learning schools it could be implemented properly. The exponential growth of Information and Communication Technology (ICT) has changed the education systems and contributed to the improvement of the learning process [11]. ICT is a means of developing learning and is an assessment and quality of learning [12]. Technology-based learning, making short videos as learning material to improve emotional relationships between students and teachers, reducing the level of difficulty and prioritize meaningful learning [13]. The second teacher respondent gave a response that this technology-based learning provided new challenges for students and teachers. This is considered sufficient to fill a temporary period during the COVID-19 pandemic so that students can continue to study even though students are not in school. Students showed a positive perception of the implementation of the blended cooperative learning model [14].

However, with online learning and being monitored by teachers who also do work from home, it is hoped that students can learn under the supervision of the teacher. After the publication of the East Java governor's circular, the East Java Provincial Education Office received intense questions and a kind of pressure from the parents / guardians of students. The question is whether internship students will also be sent home like their peers at school. This pressure arises because parents will increase the health risk of their children who are studying or working at DUDI where street vendors are. The Education Office took quick steps. Not long after the governor's letter was issued, the head of the Education Office through a circular to the heads of the Regional Education Service Branch ordered the withdrawal of internship participating vocational school students from business and industrial world institutions respectively "to be returned to teachers" (Disdik Jatim, 2020) [15]. In an emergency and uncertain situation, taxis and vocational high schools themselves circulate differently. There were those who immediately attracted street vendors as instructed, but some did not. Who does not try to take a cautious stance and attract students in a gradual and coordinative manner? The reason is, DUDI is a sensitive and sometimes not available VHS partner. Wrong, it could be that the cooperation that has been developed for a long time is terminated by DUDI [15].

The reality proves the above. The sudden withdrawal of students from street vendors has damaged a number of DUDI and VHS partnership relationships. They do not accept that internship students are suddenly withdrawn by the school. As a result, some of the management or owners of DUDI chose to cut ties with the VHS. The form of this termination is that they are no longer willing to accept school students who have been and withdraw internship students on the grounds of Kadinas or a pandemic in the next internship period in the next semester. 


\section{Conclusion}

Student internship activities will certainly be disrupted and cannot take place as it should, this forces the school to think about how the solutions must be implemented regarding internship during the COVID-19 pandemic, and things that can be done by schools include: 1) During the pandemic, halt the internship process; internship operations can resume after the pandemic has passed. (2) Relocating student street vendors to businesses that follow government and corporation laws and require the use of personal protective equipment (PPE). (3) Internships will be phased out in favor of online learning.

\section{References}

P. Sudira, Tvet abad XXI filosofi, konsep, dan strategi Press., pembelajaran vokasional. Yogyakart: UNY Press, 2016.

A. Setiyawan, "Pengembangan Sistem Informasi Penugasan dan Monitoring Siswa Prakerin Berbasis SMS Gateway dengan Raspberry Pi," Universitas Negeri Yogyakart, 2017.

Undang-Undang No. 20 tahun 2003 Tentang Sistem Pendidikan Nasional. Indonesia, 2003.

Sunyoto and A. Setiyawan, "Entrepreneurship Education in Vocational Schools in Indonesia."

A. Setiyawan, "Assignment and Monitoring Information System of Prakerin Students Based On SMS Gateway with Raspberry Pi," Environ. Sci. Technol. Mech. Eng. Educ., vol. 5, no. 1, 2020.

B. \& Eschborn, Pedoman pelaksanaan: mengembangkan kerjasama yang efektif antara lembaga dilat kejuruan dan industri. Jakarta: Kemdikbud, 2016.

A. Setiyawan, Suwachid, and D. S. Wijayanto, "Hubungan Antara Prestasi Kewirausahaan dan Prestasi Praktik Kerja Industri dengan Minat Berwirausaha Siswa Kelas XII Program Keahlian Teknik Kendaraan Ringan SMK Negeri 1 Sawit Boyolali Tahun Pelajaran 2013/2014," pp. 1-13, 2014.

T. A. Prasetya, C. T. Harjanto, and A. Setiyawan, "Analysis of student satisfaction of e-learning using the end-user computing satisfaction method during the Covid-19 pandemic," J. Phys. Conf. Ser., vol. 1700, no. 1, 2020, doi: 10.1088/1742-6596/1700/1/012012.

B. dan T. Penelitian, Metodologi Penelitian Kualitatif. Bandung: Remadja Karya, 1989.

I. W. K. Wati, A. S. Sari, Widodo, and R. Setyaningsih, "Media Need Analysis of Learning Practicum in the Covid-19 Pandemic," J. Mech. Eng. Educ., vol. 5, no. 2, 2020.

A. Setiyawan, Priyanto, T. A. Prasetya, and A. F. Hastawan, "Usability evaluation of assignment and monitoring information learning system of internship students based on SMS Gateway with Raspberry Pi Usability evaluation of assignment and monitoring information learning system of internship students based on SMS G," IOP Conf. Ser. Earth Environ. Sci., 2021, doi: 10.1088/1755-1315/700/1/012021.

Nurcholish Arifin Handoyono and Suparmin, "Online Thesis Exam Evaluation Using Zoom Cloud Meeting During the Covid-19 Pandemic," J. Mech. Eng. Educ., vol. 5, no. 2, 2020. 
H. Haiyudi and S. Art-In, "Challenges, Strategies, and Solutions of Teaching Bahasa Indonesia in Covid-19 Crises: Case in Khon Kaen University," Indones. J. Learn. Adv. Educ., vol. 3, no. 2, 2021.

R. A. Sukmawati, M. Pramita, H. S. Purba, and B. Utami, "The Use of Blended Cooperative Learning Model in Introduction to Digital Systems Learning," Indones. J. Learn. Adv. Educ., vol. 2, no. 2,2020 .

F. N. A, "Fisibilitas Penyelenggaraan PKL SMK di Masa Pandemi," Jatimtimes.com, 2020. https://jatimtimes.com/opini/232225/20201229/100600/fisibilitas-penyelenggaraanpkl-smk-di-masa-pandemi. 